\title{
Occurrence and genetic analysis of a Kemp's Ridley sea turtle (Lepidochelys kempii) in the Mediterranean Sea*
}

\author{
JESÚS TOMÁS ${ }^{1}$, ANGELA FORMIA $^{2}$, MERCEDES FERNÁNDEZ ${ }^{1}$ \\ and JUAN ANTONIO RAGA ${ }^{1}$ \\ ${ }^{1}$ Cavanilles Research Institute of Biodiversity and Evolutionary Biology and Department of Animal Biology, \\ University of Valencia. 22085, E-46071 Valencia, Spain. E-mail: jesus.tomas@uv.es \\ ${ }^{2}$ School of Biosciences, Cardiff University, Cardiff CF10 3TL, UK.
}

\begin{abstract}
SUMMARY: We report on a juvenile Kemp's Ridley sea turtle, Lepidochelys kempii, captured alive by fishermen in the waters off Alicante (western Mediterranean, Spain) on October $15^{\text {th }} 2001$. The analysis of a 460 base pair fragment of the mt DNA control region revealed a perfect match with haplotype D previously described in this species. This is the second report of L. kempii in the Mediterranean basin.
\end{abstract}

Key words: sea turtle, Lepidochelys kempii, Mediterranean, mt DNA.

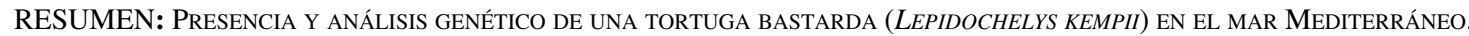
- Se cita la captura de un ejemplar vivo juvenil de tortuga bastarda (Lepidochelys kempii) por pescadores en aguas de Alicante (Mediterráneo occidental, España) el 15 de octubre de 2001. El análisis de un fragmento de 460 pares de bases de una región control de ADN mit reveló una coincidencia perfecta con el haplotipo D descrito previamente en esta especie. Esta es la segunda cita de L. kempii en el Mediterráneo.

Palabras clave: tortuga marina, Lepidochelys kempii, Mediterráneo, ADN mit.

The Kemp's Ridley turtle (Lepidochelys kempii) is the most endangered sea turtle species (National Research Council, 1990; Márquez-M., 1994). In the second half of the $20^{\text {th }}$ century the nesting population decreased from some 50,000 individuals to fewer than 5,000, with only a few hundred turtles nesting each season. However, a slow recovery of the nesting population has been detected in the last decade (Márquez-M. et al., 2001). Nesting areas of this species are restricted to the Gulf of Mexico, mainly along a stretch of beach in Rancho Nuevo,

*Received September 10, 2002. Accepted January 14, 2003.
Mexico, where mass nesting ('arribadas') occurs (Márquez-M., 1994; Márquez-M. et al., 2001). Sporadic nesting also occurs on another Mexican beach in Veracruz, and also on the U.S. coast, particularly on Padre Island, south Texas (Manzella and Williams, 1992; Shaver and Caillouet, 1998) and along the Florida coast (Johnson et al., 2000). Feeding grounds and nursery and developmental areas are distributed principally along the Gulf of Mexico and the Atlantic coast of the U.S. (Manzella et al., 1988). There is evidence of transoceanic migrations based on several recoveries of tagged turtles in the Atlantic coasts of western Europe and Morocco 


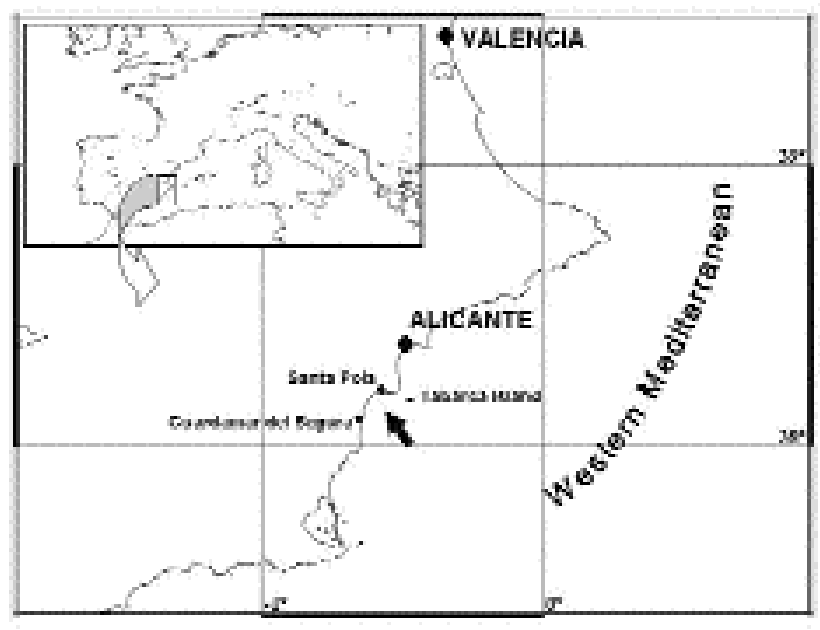

FIG. 1. - Geographical area in which a specimen of Lepidochelys kempii was captured. The black arrow indicates the probable point of capture.

(Manzella et al., 1988; references in Wilson and Zug, 1991). There is even a report of L. kempii in the Mediterranean, off the island of Malta (central Mediterranean) (Brongersma and Carr, 1983), which indicates that Kemp's Ridleys may enter the western Mediterranean basin through the Strait of Gibraltar.

On 15 October 2001, fishermen brought a sea turtle to the Municipal Aquarium of the town of Santa Pola (38 $\left.12^{\prime} \mathrm{N} 00^{\circ} 34^{\prime} \mathrm{W}\right)$, Alicante (Spain). The turtle had been captured in a gill-net deployed from a small boat. The turtle was in good condition. The fishermen did not provide the coordinates of capture, but said that it had occurred in the coastal waters (10-50 m depth) around Santa Pola, between the island of Tabarca $\left(38^{\circ} 10^{\prime} \mathrm{N} 00^{\circ} 29^{\prime} \mathrm{W}\right)$ and Guardamar del Segura (3806’N 00³9'W) (Fig. 1). We identified the turtle as $L$. kempii based on the presence of a small pore near the rear margin of each of the inframarginal scutes (Fig. 2A), the coloration of the skin, the circular shape of the carapace (Fig. 2B), the presence of five pairs of coastal scutes, and the arrangement of head scales.

Standard biometric variables of the turtle were as follows: total length $=40 \mathrm{~cm}$, curved carapace length (CCL-notch to tip) $=32.3 \mathrm{~cm}$, curved carapace width $=31.9 \mathrm{~cm}$, straight carapace length $=29.5 \mathrm{~cm}$, straight carapace width $=29 \mathrm{~cm}$, plastron length $=25$ $\mathrm{cm}$, plastron width $=24 \mathrm{~cm}$, head length $=8.2 \mathrm{~cm}$, head width $=7 \mathrm{~cm}$, total tail length $=6.6 \mathrm{~cm}$, postcloacal tail length $=2.1 \mathrm{~cm}$ and total weight $=4.6 \mathrm{~kg}$. Growth models derived from skeletochronological analysis indicate that carapace length (CL) is a good estimator of age for L. kempii (Chaloupka and Zug,
1997; Zug et al., 1997). Based on CL measurements, the age of the turtle was estimated to be 3 or 4 years. The specimen had only one pair of claws on its front flippers (Fig. 2B), instead of two as is typical for the species (Pritchard and Mortimer, 1999). This reduction in the number of claws has also been observed in some adults, and has been interpreted as the result of a secondary loss (Pritchard and Mortimer, 1999). The specimen also had a small scar on the dorsal side of the neck, and a notch from an old wound on the right side of the beak.

Genetic analysis of mitochondrial (mt) DNA markers has been used within the context of phylogeographic studies of sea turtles worldwide. A small skin biopsy was taken from the dorsal side of the anterior left flipper and stored in $96 \%$ ethanol. DNA was subsequently extracted using a standard phenol:chloroform protocol (Sambrook et al.,

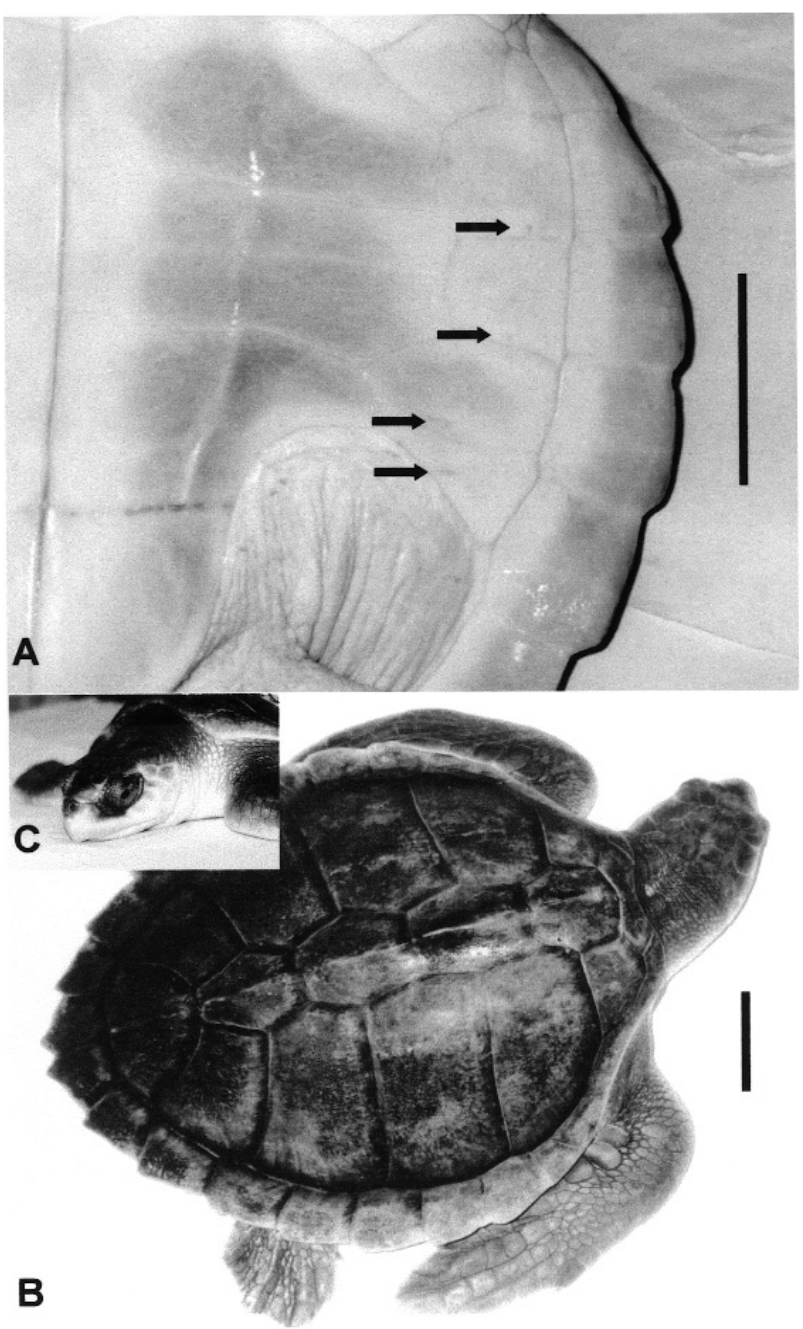

FIG. 2. - A, Detail of the pores (arrows) of the inframarginal scutes of Lepidochelys kempii incidentally captured off Alicante coast (western Mediterranean, Spain). B, Dorsal view of the specimen. C, Detail of the head. Scale bars: $5 \mathrm{~cm}$. 
1989) and preserved in TE buffer at $-20^{\circ} \mathrm{C}$. Polymerase Chain Reaction (PCR) was used to amplify a 460 base pair fragment of the mitochondrial (mt) DNA control region comparable to that analysed by Bowen et al. (1998), using primers LTCM2 (Encalada et al., 1996), HDCM1 (Allard et al., 1994), LTCM1.1 and HDCM1.1 (Formia, unpublished data). PCR products were double-sequenced with the ABI Prism Big Dye Terminator kit V.2 and analysed with an ABI 3100 sequencer (Applied Biosystems). Sequences were aligned and edited using Sequencher 3.1.2 (Gene Codes Corporation). The sequence obtained perfectly matched haplotype D previously observed in five individuals stranded on the Atlantic coast of the U. S. and Gulf of Mexico (Bowen et al., 1998) (GenBank accession number AF051777). However, since the control region haplotype distribution of Kemp's Ridleys in nesting and oceanic habitats is still unknown, we cannot speculate on the origin of this individual, beyond the fact that its mt DNA was inherited from a female Kemp's Ridley. Depending on its natal origin (Rancho Nuevo, South Texas or Florida), this specimen would have navigated a distance of between 8,500 and $10,000 \mathrm{~km}$. The actual distance could have been even longer if the turtle had swum the North Atlantic Gyre (see references in Márquez-M., 1994).

This is the second report of a Kemp's Ridley in the Mediterranean Sea, and confirms the passage of this species into this sea through the Strait of Gibraltar. Some authors suggest that pelagic juveniles leaving the Gulf of Mexico are lost for the breeding population (see references in Musick and Limpus, 1997). However, due to the high number of L. kempii juveniles around the Atlantic reported in the literature, it is possible that this ocean and even the Mediterranean Sea form part of the extended range for this species.

\section{ACKNOWLEDGEMENTS}

We especially thank the fishermen and the staff of the Municipal Aquarium of Santa Pola (particularly E. Antón) for their interest and collaboration. We are also grateful for the economic support of the
Conselleria de Territori i Habitatge of the Generalitat Valenciana.

\section{REFERENCES}

Allard, M.W., M.M. Miyamoto, K.A. Bjorndal, A.B. Bolten and B.W. Bowen. - 1994. Support for natal homing in green turtles from mitochondrial DNA sequences. Copeia, 1994: 34-41.

Bowen, B.W., A.M. Clark, F.A. Abreu-Grobois, A. Chaves, H.A. Reichart and R.J. Ferl. - 1998. Global phylogeography of the ridley sea turtles (Lepidochelys spp.) as inferred from mitochondrial DNA sequences. Genetica, 101: 179-189.

Brongersma, L.D. and A.F. Carr. - 1983. Lepidochelys kempii (Garman) from Malta. Proc. K. Ned. Akad. Wet. Ser. C Biol. Med. Sci., 86: 445-454.

Chaloupka, M. and G.R. Zug. - 1997. A polyphasic growth function for the endangered Kemp's ridley sea turtle Lepidochelys kempii. Fish. B.-NOAA., 95: 849-856.

Encalada, S.E., P.N. Lahanas, K.A. Bjorndal, A.B. Bolten, M.M. Miyamoto and B.W. Bowen. - 1996. Phylogeography and population structure of the Atlantic and Mediterranean green turtle Chelonia mydas: a mitochondrial DNA control region sequence assessment. Mol. Ecol., 5: 473-483.

Johnson, S.A., A.L. Bass, B. Libert, M. Marshall and D. Fulk. 2000. Kemp's ridley (Lepidochelys kempii) nesting in Florida. Fla Sci., 62: 194-204.

Manzella, S.A. and J.A. Williams. - 1992. The distribution of Kem$p$ 's ridley sea turtle (Lepidochelys kempii) along the Texas coast: an atlas. U.S. Dep. Commer., NOAA Tech. Memo. NMFS-SEFCSC-110. pp. 1-52.

Manzella, S.A., C.W. Caillouet, and C.T. Fontaine. - 1988. Kemp`s ridley, Lepidochelys kempii, sea turtle head start tag recoveries: Distribution, habitat, and method of recovery. Mar. Fish. Rev., 50(3): 24-32.

Márquez-M., R. - 1994. Synopsis of the biological data on the Kemp's ridley turtle Lepidochelys kempii (Garman 1880). U.S. Dep. Commer., NOAA Tech. Memo. NMFS-SEFCSC343, pp. 1-91.

Márquez-M., R., P. Burchfield, M.A. Carrasco, C. Jiménez, J. Díaz, M. Garduño, A. Leo, J. Peña, R. Bravo and E. González. 2001. Update on the Kemp's ridley turtle nesting in México. Mar. Turtle. Newsl., 92: 2-4.

Musick, J.A. and C.J. Limpus. - 1997. Habitat utilization and migration in juvenile sea turtles. In: P.L. Lutz and J.A. Musick (eds.), The biology of sea turtles, pp. 51-81. CRC Marine Science Series, CRC Press, Boca Raton.

National Research Council. - 1990. Decline of the Sea Turtles: Causes and Preventions. National Academy Press, Washington.

Pritchard, P.C.H. and J.A. Mortimer. - 1999. Taxonomy, external morphology, and species identification. In: K.L. Eckert, et al. (eds.), Research and management techniques for the conservation of sea turtles. IUCN/SSC Marine Turtle Specialist Group Publication No. 4. pp. 21-38.

Sambrook, J., E.F. Fitsch and T. Maniatis. - 1989. Molecular Cloning- A Laboratory Manual, Second Edition. Cold Spring Harbor Laboratory Press, New York.

Shaver, D.J. and C.W. Caillouet Jr. - 1998. More Kemp's ridley turtles return to south Texas to nest. Mar. Turtle Newsl., 82: 1-5.

Wilson, R.V. and G.R. Zug. - 1991. Lepidochelys kempii. In: C.H. Ernst (ed.) Catalogue of American Amphibians and Reptiles. pp. 509.1-509.8. The Society for the Study of Amphibians and Reptiles.

Zug., G.R., H.J. Kalb and S.J. Luzar. - 1997. Age and growth in wild Kemp's ridley sea turtle Lepidochelys kempii from skeletochronological data. Biol. Conserv., 80: 261-268.

Scient. ed.: P. Abelló 